\title{
PENGUKURAN TINGKAT EKO-EFISIENSI MENGGUNAKAN METODE LIFE CYCLE ASSESSMENT (LCA) UNTUK MENCIPTAKAN PRODUKSI BATIK YANG EFISIEN DAN RAMAH LINGKUNGAN (Studi Kasus di UKM Sri Kuncoro Bantul)
}

\author{
Yulius Windrianto, Dyah Rachmawati L. Intan Berlianty \\ Jurusan Teknik Industri Fakultas Teknik Industri \\ Universitas Pembangunan Nasional "Veteran" Yogyakarta \\ Jl. Babarsari 2 Tambakbayan, Yogyakarta, 55281
}

Telp. (0274) 485363 Fax.: (0274) 486256 email : jur_tiupn@telkom.net

\begin{abstract}
ABSTRAK
Penelitian ini dilakukan di industri batik Sri Kuncoro, desa Giriloyo, Imogiri, Bantul. Tujuan dari penelitian ini adalah mendapatkan alternatif terbaik untuk memperbaiki produksi batik tulis pewarna sintetis Sri Kuncoro sehingga diperoleh produksi batik yang efisien dan ramah lingkungan.

Metode yang digunakan adalah Life Cycle Assessment (LCA) dan Eco-Efficiency Ratio (EER). Metode LCA merupakan metode untuk mengidentifikasi dan menghitung penggunaan energi, penggunaan sumber daya alam, dan pembuangan pada lingkungan, serta mengevaluasi dan menerapkan kemungkinan perbaikan lingkungan. Metode LCA dilakukan melalui empat tahap yaitu goal and scope, Life Cycle Inventory (LCI), Life Cycle Impact Assessment (LCIA), dan interpretasi. Metode Eco-Efficiency Ratio (EER) merupakan metode untuk mengetahui tingkat sustainable suatu produk.

Dari hasil penelitian menunjukkan bahwa untuk memperbaiki produksi batik dibutuhkan alternatif pengganti, yaitu mengganti kompor minyak tanah dengan kompor listrik pada proses pembatikan, dan mengganti kayu bakar dengan bahan bakar gas pada proses nglorod. Nilai EER pada produksi batik Sri Kuncoro sebesar $56 \%$, dan batik alternatif pengganti sebesar $60 \%$ dengan nilai affordable dan sustainable lebih besar dari 1.
\end{abstract}

Kata kunci : Life Cycle Assessment (LCA), Eco-Efficiency Ratio (EER), batik.

\section{PENDAHULUAN}

Saat ini batik sudah menjadi identitas yang begitu melekat dengan masyarakat Indonesia. Dari anak muda hingga orang tua maupun kalangan bawah hingga kalangan atas juga menggunakannya. Tak sedikit pula orang-orang mancanegara yang tertarik dengan kain bermotif khas Indonesia. Banyak varian dan ragam batik berdasarkan tempat asal maupun cara pembuatannya, hal ini membuat batik kaya akan motif dan jenisnya.

Yogyakarta merupakan salah satu kota yang menjadi sentra industri batik terbesar di Indonesia. Industri batik Sri Kuncoro adalah satu dari beberapa industri batik yang berada di desa Giriloyo, Bantul. Kelompok batik tersebut mengerjakan batik dengan prioritas batik tulis tangan dengan major product-nya berupa kain batik. Batik yang diproduksi terdiri dari dua jenis metode pembuatan yakni pembuatan batik melalui pewarna alam maupun sintetis. Untuk batik sintetis yang diproduksi menggunakan pewarna naphtol. Bahan pewarna kimia pada batik tersebut tergolong tidak ramah lingkungan. Apabila limbah-limbah mengalir ke dalam tanah atau sungai, bahan-bahan tersebut tentu merusak ekosistem tanah dan air. Efek negatif pewarna kimia dalam proses pewarnaan oleh pengrajin batik adalah risiko terkena kanker kulit. Akibatnya, kulit tangan yang bersinggungan dengan pewarna kimia berbahaya seperti naphtol yang termasuk dalam kategori B3 (bahan beracun berbahaya) ini dapat memacu kanker kulit. Penggunaan bahan bakar minyak tanah yang merupakan bahan bakar yang bersumber dari fosil juga terdapat dampak negatif yaitu pencemaran lingkungan dari hasil pembakaran yang dapat mengakibatkan pemanasan global, berdampak pada kesehatan manusia yang menyebabkan gangguan pernafasan, dan menipisnya bahan bakar fosil karena penggunaan bahan bakar yang berlebihan. Industri batik Sri Kuncoro tidak hanya menggunakan bahan bakar 
minyak tanah pada proses pembatikan tetapi juga menggunakan bahan bakar kayu pada proses nglorod. Dampak yang ditimbulkan dari penggunaan bahan bakar kayu juga dapat mencemari lingkungan dan berbahaya bagi kesehatan manusia.

Sebagai upaya untuk menekan penggunaan bahan bakar dan bahan kimia yang kurang ramah lingkungan dan untuk meminimasi limbah yang dihasilkan pada proses industri batik, perlu adanya penerapan pembangunan berkelanjutan. Menurut Brutland Report (1987) seperti dikutip Agustin (2015) pembangunan berkelanjutan merupakan proses pembangunan yang berprinsip untuk memenuhi kebutuhan sekarang tanpa mengorbankan kebutuhan generasi yang akan datang.

Menurut Astuti et al. (2004), salah satu alat yang bisa digunakan untuk mengevaluasi dampak produk terhadap lingkungan adalah Life Cycle Assessment (LCA). LCA merupakan metode untuk mengidentifikasi dan menghitung penggunaan energi, penggunaan sumber daya alam, dan pembuangan pada lingkungan, serta mengevaluasi dan menerapkan kemungkinan perbaikan lingkungan. Dengan mengetahui seberapa besar dampak yang ditimbulkan terhadap lingkungan, sehingga dapat menentukan perbaikan dengan melakukan penggantian pada material atau energi guna meminimalisir dampak yang ditimbulkan.

\section{LANDASAN TEORI}

\subsection{Eko-efisiensi}

Eko-efisiensi merupakan suatu filosofi manajemen yang mendorong suatu bisnis untuk mencari perbaikan terhadap lingkungan yang dapat memberikan manfaat ekonomi yang bersifat paralel. Seperti yang diartikan oleh World Business Council for Sustainable Development (WBCSD) bahwa eko-efisiensi dapat dicapai dengan membuat suatu harga produk yang kompetitif dan pelayanan yang memuaskan untuk kebutuhan manusia dan memberikan kualitas dari hidup, mengurangi dampaknya terhadap lingkungan dan intensitas keluaran dari sumber daya yang digunakan serta level dari life cycle dengan estimasi dari kapasitas yang dapat diterima oleh lingkungan. Singkatnya ekoefisiensi lebih berfokus pada membuat suatu nilai/produk dengan dampak yang minimal "doing more value with less impact" (Verfaillie dan Bidwell, 2000).

\subsection{Life Cycle Assessment (LCA)}

Life Cycle Assessment (LCA) merupakan suatu metode yang digunakan untuk mengestimasikan energi atau aliran material yang berhubungan dengan siklus hidup produk yang berpengaruh pada dampak ke lingkungan (Fiksel, 2011). Life Cycle Assessment (LCA) meliputi beberapa tahapan, antara lain (Horne, 2009):

1. Goal and Scope

Tahap ini bertujuan untuk memformulasikan dan mendeskripsikan tujuan, sistem yang akan dievaluasi, batasan-batasan dan asumsi-asumsi yang berhubungan dengan dampak di sepanjang siklus hidup dari sistem.

2. Life Cycle Inventory (LCI)

Merupakan proses kuantifikasi kebutuhan energi dan material, emisi udara, limbah padat dan semua keluaran yang dibuang ke lingkungan selama daur hidup produk.

3. Life Cycle Impact Assessment (LCIA)

Tahap Life Cycle Impact Assessment (LCIA) merupakan tahap analisa mengenai jenis dan besarnya nilai tiap kategori dampak yang dihasilkan (nilai Eco-costs) menggunakan metode Eco-costs 2012, nilai dan indikator dari Eco-costs berdasarkan standar dari WBCSD (World Business Council for Sustainable Development). Pada fase LCIA terbagi lagi menjadi beberapa tahapan analisa diantaranya (Vogtlander et al, 2010):

a. Klasifikasi dan karakterisasi Klasifikasi merupakan langkah untuk mengidentifikasi dan mengelompokkan substansi yang berasal dari LCI ke dalam kategori II-23

dampak yang heterogen yang telah ditentukan sebelumnya sedangkan karakterisasi merupakan penilaian besarnya substansi yang berkontribusi 
pada kategori dampak.

b. Normalisasi

Prosedur yang diperlukan untuk menunjukkan kontribusi relatif dari semua kategori dampak pada seluruh masalah lingkungan untuk menciptakan satuan yang seragam untuk semua kategori impact dengan mengalikan nilai karakterisasi dengan nilai normal.

c. Pembobotan

Pembobotan didapatkan dengan mengalikan kategori impact dengan faktor pembobotan dan ditambahkan untuk mendapatkan nilai total.

d. Single score

Digunakan

untuk mengklasifikasikan nilai kategori impact berdasarkan aktivitas atau proses. Nilai single score akan terlihat aktivitas mana yang berkontribusi terhadap dampak lingkungan.

4. Interpretasi

Mengevaluasi hasil dan mengimplementasikan kesempatan unntuk pengembangan lebih lanjut.

\subsection{Eco-costs}

Eco-costs adalah ukuran untuk menyatakan jumlah dampak lingkungan dari suatu produk atas dasar pencegahan dampak itu sendiri. Ini adalah biaya yang harus dikeluarkan untuk mengurangi polusi dan berkurangnya bahan material yang ada di bumi. Konsep dari Eco-costs merupakan konsep biaya bayangan atau shadow prices, biaya bayangan merupakan suatu poin dimana biaya-biaya pencegahan bertemu dengan biaya-biaya kerusakan yang dihasilkan di dalam suatu sistem perdagangan bebas. Bagaimanapun, kalkulasi perhitungan di dalam Eco-costs memberikan hasil sebagai kalkulasi di dalam biaya kerusakan (TU Delft, 2015).

\subsection{Cost Benefit Analysis (CBA)}

Cost Benefit Analysis (CBA) digunakan untuk menghitung net value dari suatu produk. Net value ini diperoleh dengan mengurangi harga jual dengan Harga Pokok Produksi (HPP), sehingga besarnya nilai dari net value ini dipengaruhi oleh biaya-biaya yang dibutuhkan dalam produksi suatu produk dan nilai penjualan dari produk tersebut.

\subsection{Eco Efficiency Index (EEI)}

Perhitungan ini berfungsi untuk mengetahui nilai affordable dan sustainable. Input EEI berupa besar Eco-costs yang dihasilkan dan besar net value produk dengan input nilai rasio kelayakan keuntungan (benefit cost).

Menurut Tak Hur et al. (2003), perhitungan Eco Efficiency Index (EEI) berfungsi untuk mengetahui nilai affordable dan sustainable dari produksi (persamaan 2.1).

$$
\begin{gathered}
E E I= \\
\text { Price }- \text { Cost }
\end{gathered}
$$

Tabel 2.1 Kriteria Eco Efficenci Index

\begin{tabular}{|l|l|l|}
\hline $\begin{array}{l}\text { Eco-efficiency } \\
>1\end{array}$ & affordable, & sustainable \\
\hline$=0-1$ & affordable, & $\begin{array}{l}\text { not } \\
\text { sustainable }\end{array}$ \\
$<0$ & $\begin{array}{l}\text { not } \\
\text { affordable, }\end{array}$ & $\begin{array}{l}\text { not } \\
\text { sustainable }\end{array}$ \\
\hline $\mathbf{2 . 6}$ & $\begin{array}{l}\text { Eco-costs Value Ratio (EVR) } \\
\text { Eco-costs Value Ratio (EVR) }\end{array}$
\end{tabular}

digunakan untuk menghitung nilai dari tingkat Eco Efficiency Ratio (EER), sehingga dari perhitungan ini dapat diketahui hasil tingkat efisiensi dari suatu proses pembuatan suatu produk.

Nilai dari EVR ini diperoleh dari membagi Eco-costs dengan net value, dari sini hasil kalkulasi antara net value yang diperoleh dari interpretasi analisis LCA, sehingga akan dihasilkan suatu nilai yang disebut Eco Efficiency Ratio (EER). Persamaan 2.2 berikut merupakan rumus untuk menghitung nilai EVR (Vogtlander et al, 2010).

$$
\begin{gathered}
E V R= \\
\frac{E \text { co } \text { costs }}{\text { Net Value ............... }} .
\end{gathered}
$$

\subsection{Eco Efficiency Ratio (EER)}

Menurut Vogtlander et al. (2010) hasil perhitungan EER Rate diperoleh dengan cara membagi nilai Eco-cost yang dihasilkan dengan nilai net value yang diperoleh sehingga diketahui rasio Eco-costs dengan net value kemudian hasilnya dikurangkan dengan 1 dan dikalikan 100\% (persamaan 2.3). Adapun data yang digunakan untuk menghitung nilai EEI antara lain biaya dari hasil representasi nilai atau output Eco-costs dan besar net value produk. 
EER Rate $=(1-E V R) 100 \%$

\section{METODOLOGI PENELITIAN 3.1 Pengumpulan Data}

Untuk mempermudah dalam penelitian ini maka harus didukung dengan data yang berhubungan dengan kegiatan ini, data tersebut adalah :

1. Data wawancara

Data ini diperoleh secara langsung melalui wawancara dengan para pekerja produksi serta pihak perusahaan untuk mengetahui proses produksi batik tulis pewarna sintetis, jumlah bahan baku yang digunakan, jenis bahan baku yang digunakan, bahan bakar yang digunakan, biaya listrik, biaya tenaga kerja, harga jual produk, harga bahan baku.

2. Teknik pengumpulan data dilakukan secara langsung dengan cara melakukan pengamatan untuk mengetahui proses produksi secara langsung, alat-alat yang digunakan, jumlah bahan baku yang digunakan, jumlah tenaga kerja.

3. Suatu cara yang dilakukan untuk mendapatkan informasi mengenai segala hal yang dilakukan dalam penelitian seperti harga alat, harga bahan baku, dan jurnal-jurnal untuk membantu dalam penelitian.

\subsection{Pengolahan Data}

Data penelitian ini terdapat beberapa tahap dalam melakukan pengolahan data yaitu:

1. Life Cycle Assessment (LCA)

Menghitung Life Cycle Assessment (LCA) produk dengan proses dan material yang digunakan perusahaan dengan tahap sebagai berikut:

a. Goal and scope

Menentukan batasan siklus hidup produk yang akan dibahas pada penelitian yang disesuaikan dengan data yang telah dikumpulkan sebelumnya.

b. Life Cycle Inventory (LCI)

Data yang diperlukan dalam penilaian dampak lingkungan produk dikumpulkan sesuai dengan batasan siklus hidup yang telah ditentukan sebelumnya. Termasuk di dalamnya data Eco- costs yang merupakan indikator dampak lingkungan setiap komponen produk.

c. Life Cycle Impact Assessment (LCIA)

Perhitungan nilai dampak lingkungan produk dilakukan pada tahap ini dengan menggunakan software SimaPro versi 8.2 dan perhitungan manual. Tahap ini terdapat 4 tahap yaitu karakterisasi, normalisasi, pembobotan, dan single score.

d. Interpretation

Dijelaskan hasil dari penilaian dampak lingkungan produk dengan proses dan material yang digunakan.

2. Cost Benefit Analysis (CBA)

Cost Benefit Analysis (CBA)

digunakan untuk menghitung net value dari suatu produk. Input dari net value ini antara lain biaya-biaya yang terkait dalam proses produksi serta harga jual dari produk batik.

3. Eco Efficiency Index (EEI)

Perhitungan ini untuk mengetahui nilai affordable dan sustainable. Input EEI berupa besar Eco-costs yang dihasilkan dan besar net value produk dengan input nilai rasio kelayakan keuntungan (benefit cost).

4. Eco-costs Value Ratio (EVR) Eco-costs Value Ratio (EVR) digunakan untuk menghitung nilai dari tingkat Eco Efficiency Ratio (ERR), sehingga dari perhitungan ini dapat diketahui hasil tingkat efisiensi dari suatu proses pembuatan suatu produk.

5. Eco Efficiency Ratio (EER) EER merupakan perhitungan terakhir untuk mengetahui tingkat ekoefisiensi produk dalam persentase harga. 


\section{PENGOLAHAN DATA DAN} ANALISIS HASIL

\subsection{Perhitungan Life Cycle Assessment (LCA)}

4.1.1 Goal and scope

Sasaran dalam LCA ini adalah mengetahui dampak ekologi yang dihasilkan serta menentukan alternatif pengganti material dan energi produksi batik tulis pewarna sintetis yang efisien dan ramah lingkungan. Sistem yang dievaluasi dalam LCA yaitu pada dampak lingkungan yang

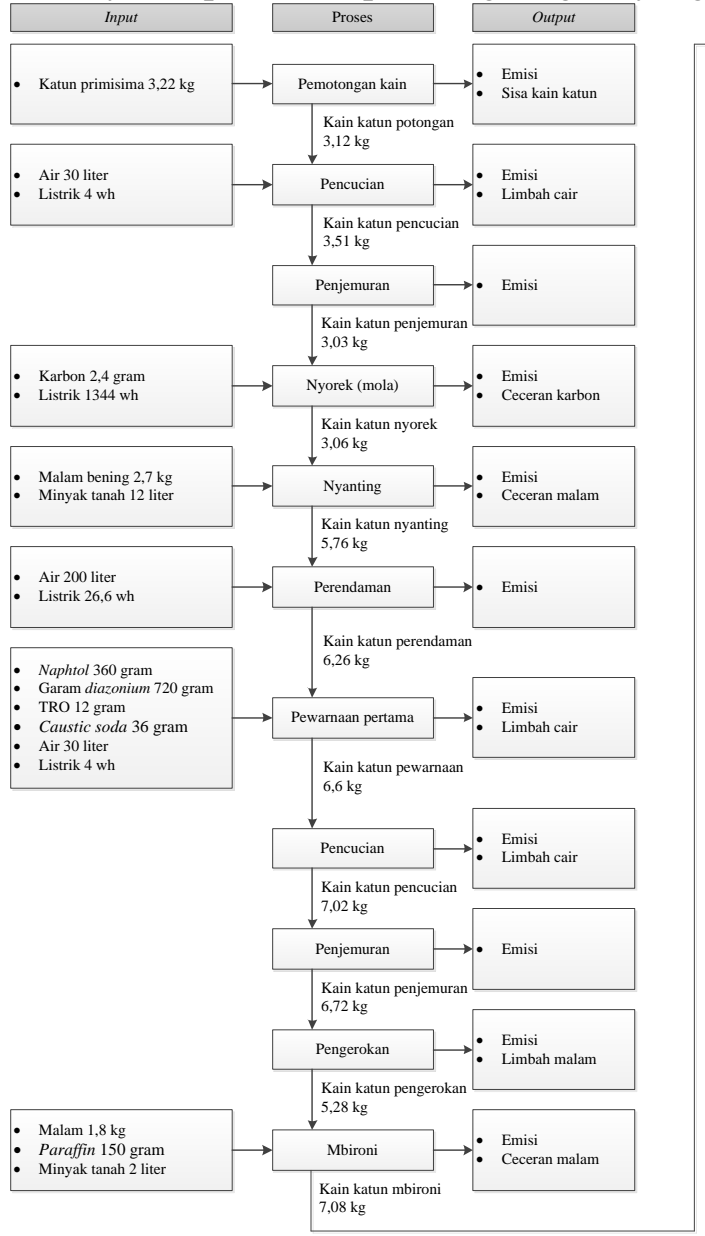

dihasilkan pada proses produksi batik tulis pewarna sintetis di industri batik Sri Kuncoro dan dampak lingkungan yang dihasilkan dari proses produksi batik alternatif.

4.1.2 Perhitungan Life Cycle Inventory (LCI)

Gambar 4.1 berikut merupakan langkah dalam pembuatan batik tulis pewarna sintetis beserta kebutuhan bahan yang digunakan pada industri batik Sri Kuncoro untuk memproduksi 12 lembar batik tulis pewarna sintetis.

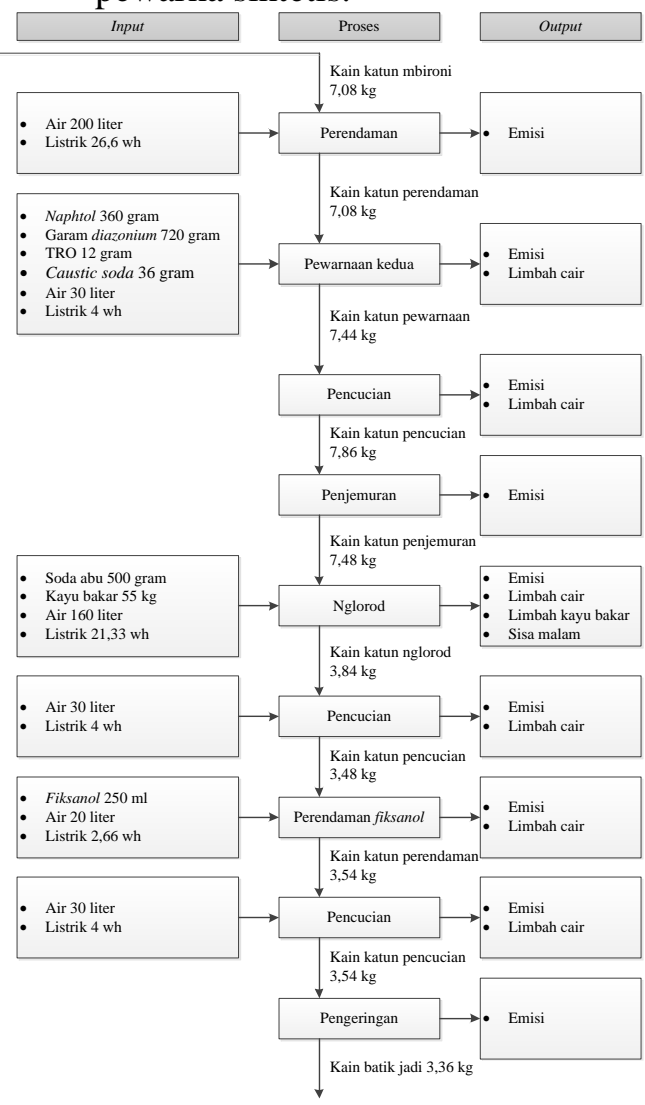

Gambar 4.1 Diagram alir proses produksi batik tulis pewarna sintetis

\subsubsection{Perhitungan Life Cycle Impact} Assessment (LCIA)

1. Batik tulis pewarna sintetis Sri Kuncoro

Berikut ini adalah Tabel 4.1 yang menunjukkan hasil output software Simapro untuk kalkulasi pembobotan kain batik tulis Sri Kuncoro. Hasil perhitungan ini adalah biaya pencegahan dari emisi yang diperoleh dari kalkulasi antara hasil normalisasi dengan standar biaya pencegahan emisi Eco-costs 2012.

Tabel 4.1 Hasil output software Simapro

\begin{tabular}{|l|c|c|}
\multicolumn{1}{|c|}{ LCIA } \\
$\begin{array}{c}\text { Kategori } \\
\text { dampak }\end{array}$ & $\begin{array}{c}\text { Batik } \\
\text { Sri } \\
\text { Kuncoro } \\
(\boldsymbol{(})\end{array}$ & $\begin{array}{c}\text { Batik Sri } \\
\text { Kuncoro } \\
(\mathbf{R p})\end{array}$ \\
\hline $\begin{array}{l}\text { Climate } \\
\text { change }\end{array}$ & 42,352 & 618.974 \\
\hline Acidification & 14,117 & 206.321 \\
\hline
\end{tabular}


Tabel 4.1 Hasil output software Simapro LCIA (lanjutan)

\begin{tabular}{|l|r|r|}
\hline \multicolumn{1}{|c|}{$\begin{array}{c}\text { Kategori } \\
\text { dampak }\end{array}$} & \multicolumn{1}{c|}{$\begin{array}{c}\text { Batik } \\
\text { Sri } \\
\text { Kuncoro } \\
(\boldsymbol{\epsilon})\end{array}$} & \multicolumn{1}{c|}{$\begin{array}{c}\text { Batik Sri } \\
\text { Kuncoro } \\
(\mathbf{R p})\end{array}$} \\
\hline Eutrophication & \multicolumn{1}{c|}{3,491} & 51.027 \\
\hline $\begin{array}{l}\text { Photochemical } \\
\text { oxidant } \\
\text { formation }\end{array}$ & 0,337 & 4.921 \\
\hline Fine dust & 13,621 & 199.069 \\
\hline $\begin{array}{l}\text { Human } \\
\text { toxicity }\end{array}$ & 19,275 & 281.710 \\
\hline $\begin{array}{l}\text { Exotoxicity } \\
\text { (freshwater) }\end{array}$ & 3,808 & 55.650 \\
\hline $\begin{array}{l}\text { Metals } \\
\text { depletion }\end{array}$ & 3,123 & 45.643 \\
\hline $\begin{array}{l}\text { Oil \& gas } \\
\text { depletion excl } \\
\text { energy }\end{array}$ & 0 & 0 \\
\hline Waste & 395,613 & 5.781 .878 \\
\hline Land-use & 0 & 0 \\
\hline $\begin{array}{l}\text { Water stress } \\
\text { indicator }\end{array}$ & 8,564 & 125.160 \\
\hline \multicolumn{1}{|c|}{ Total } & $\mathbf{5 0 4 , 3 0 1}$ & $\mathbf{7 . 3 7 0 . 3 5 3}$ \\
\hline
\end{tabular}

2. Batik tulis pewarna sintetis alternatif Dari hasil perhitungan LCIA pada setiap alternatif maka diperoleh proses produksi batik alternatif yang memiliki biaya pencegahan emisi paling sedikit yaitu pada proses pembatikan menggunakan kompor listrik, pada proses pewarnaan menggunakan pewarna naphtol, dan pada proses nglorod menggunakan bahan bakar gas. Pada Tabel 4.2 yang menunjukkan hasil output software Simapro untuk kalkulasi pembobotan proses produksi batik tulis pewarna sintetis pada batik alternatif.

Tabel 4.2 Hasil output software Simapro LCIA

\begin{tabular}{|l|r|r|}
\hline \multicolumn{1}{|c|}{$\begin{array}{c}\text { Kategori } \\
\text { dampak }\end{array}$} & \begin{tabular}{c}
\multicolumn{1}{c|}{ Batik } \\
alternatif $(\boldsymbol{€})$
\end{tabular} & $\begin{array}{c}\text { Batik } \\
\text { alternatif } \\
\text { (Rp) }\end{array}$ \\
\hline $\begin{array}{l}\text { Climate } \\
\text { change }\end{array}$ & 38,588 & 563.964 \\
\hline Acidification & 12,665 & 185.100 \\
\hline Eutrophication & 3,247 & 47.452 \\
\hline $\begin{array}{l}\text { Photochemical } \\
\text { oxidant } \\
\text { formation }\end{array}$ & 0,253 & 3.691 \\
\hline Fine dust & 13,366 & 195.338 \\
\hline
\end{tabular}

\begin{tabular}{|l|r|r|}
\hline $\begin{array}{l}\text { Human } \\
\text { toxicity }\end{array}$ & 17,987 & 262.874 \\
\hline $\begin{array}{l}\text { Exotoxicity } \\
\text { (freshwater) }\end{array}$ & 3,550 & 51.883 \\
\hline $\begin{array}{l}\text { Metals } \\
\text { depletion }\end{array}$ & 2,747 & 40.147 \\
\hline $\begin{array}{l}\text { Oil \& gas } \\
\text { depletion excl } \\
\text { energy }\end{array}$ & 0 & 0 \\
\hline Waste & 365,455 & 5.341 .125 \\
\hline Land-use & 0 & 0 \\
\hline $\begin{array}{l}\text { Water stress } \\
\text { indicator }\end{array}$ & 8,174 & 119.457 \\
\hline \multicolumn{2}{|c|}{ Total } \\
\multicolumn{2}{|c|}{ 4.2 Perhitungan Cost Benefit Analysis } \\
(CBA)
\end{tabular}

4.2.1 Perhitungan Harga Pokok Produksi (HPP)

Perhitungan harga pokok produksi merupakan penjumlahan dari semua biaya yang dikeluarkan dalam memproduksi batik tulis pewarna sintetis. Harga Pokok Produksi (HPP) batik Sri Kuncoro dan batik alternatif terbaik dapat dilihat pada Tabel 4.3 berikut ini.

Tabel 4.3 Harga Pokok Produksi (HPP)

\begin{tabular}{|c|c|c|c|}
\hline \multicolumn{2}{|c|}{ Jenis biaya } & $\begin{array}{c}\text { Batik Sri } \\
\text { Kuncoro } \\
\text { (Rp) }\end{array}$ & $\begin{array}{c}\text { Batik } \\
\text { Alternatif } \\
(\mathbf{R p})\end{array}$ \\
\hline \multicolumn{2}{|c|}{ Biaya bahan baku } & 1.923 .450 & 1.810 .400 \\
\hline \multicolumn{2}{|c|}{ Biaya tenaga kerja } & 2.616 .000 & 2.616 .000 \\
\hline \multirow[b]{2}{*}{$\begin{array}{l}\text { Biaya } \\
\text { overhead }\end{array}$} & $\begin{array}{l}\text { Biaya } \\
\text { listrik }\end{array}$ & 3.657 & 8.249 \\
\hline & $\begin{array}{l}\text { Biaya } \\
\text { penyusutan } \\
\text { alat }\end{array}$ & 138.907 & 149.827 \\
\hline \multicolumn{2}{|c|}{ Total biaya } & 4.682 .014 & 4.584 .476 \\
\hline \multicolumn{2}{|c|}{$\begin{array}{lll}\text { HPP } & 1 & \text { lembar kain } \\
\text { batik } & & \end{array}$} & 390.168 & 382.040 \\
\hline
\end{tabular}

4.2.2 Perhitungan net value

Produksi batik tulis pewarna sintetis pada industri batik Sri Kuncoro memiliki harga Rp 1.800.000 per lembar. Perhitungan net value dapat diketahui dengan hasil sebagai berikut:

Net value batik Sri Kuncoro $=\mathrm{Rp}$ 1.800 .000 - Rp 390.168

$$
=\operatorname{Rp} 1.409 .832
$$

Net value batik alternatif $\quad=\mathrm{Rp}$

$$
\begin{array}{r}
1.800 .000 \text { - Rp } 382.040 \\
=\text { Rp } 1.417 .960
\end{array}
$$

Jadi, net value atau keuntungan bersih industri batik Sri Kuncoro sebesar Rp 
1.409.832,- dan net value dari alternatif terbaik sebesar $\mathrm{Rp}$ 1.417.960,- dalam memproduksi satu lembar batik tulis pewarna sintetis

\subsection{Perhitungan Eco Efficiency Index (EEI), Eco-costs Value Rate (EVR, dan Eco Efficiency Ratio (EER)}

4.3.1 Perhitungan Eco Efficiency Index (EEI)

Berikut ini adalah perhitungan EEI dengan tujuan untuk mengetahui nilai affordable dan sustainable dari produksi batik tulis pewarna sintetis. Perhitungan EEI dapat diketahui dengan hasil sebagai berikut: EEI batik Sri Kuncoro =

$$
\begin{aligned}
& \text { Rp 1.800.000-Rp } 390.168 \\
& \text { Rp 390.168 + Rp } 614.196 \\
& =\frac{\operatorname{Rp} 1.409 .832}{\operatorname{Rp} 1.004 .364} \\
& =1,40 \\
& =\frac{\operatorname{Rp} 1.417 .960}{\operatorname{Rp} 949.628} \\
& =1,49
\end{aligned}
$$

EEI batik alternatif $=$

Dari perhitungan yang telah dilakukan didapatkan nilai EEI batik tulis pewarna sintetis Sri Kuncoro dengan nilai 1,40 dan nilai EEI batik tulis pewarna sintetis alternatif dengan nilai 1,49 . Sehingga dapat dikatakkan produk batik tulis pewarna sintetis Sri Kuncoro dan produk batik tulis pewarna sintetis alternatif sama-sama bersifat affordable dan sustainable.

4.3.2 Perhitungan Eco-costs Value Rate (EVR)

Berikut ini adalah perhitungan EVR yang diperoleh dengan cara membagi nilai eco-costs dengan nilai net value.

$E V R$ batik Sri Kuncoro $=\frac{\operatorname{Rp} 614.196}{\operatorname{Rp~} 1.409 .832}$

$$
=0,44
$$

EVR batik alternatif $\quad=\frac{\operatorname{Rp} 567.588}{\operatorname{Rp} 1.417 .960}$

$$
=0,40
$$

\subsubsection{Perhitungan Eco Efficiency Ratio \\ (EER) \\ Nilai EER ini menunjukan tingkat} eko-efisiensi dari proses produksi batik tulis pewarna sintetis.

$$
\begin{aligned}
\text { EER batik Sri Kuncoro } & =(1-0,44) 100 \% \\
& =56 \% \\
\text { EER batik alternatif } & =(1-0,40) 100 \% \\
& =60 \%
\end{aligned}
$$

Dari perhitungan diatas dapat diketahui bahwa nilai EER dari batik tulis pewarna sintetis Sri Kuncoro sebesar 56\% dan batik tulis pewarna sintetis alternatif sebesar $60 \%$.

\subsection{Analisis Hasil}

4.4.1 Analisis hasil LCA

Tabel 4.4 Kategori dampak terbesar batik tulis pewarna sintetis Sri Kuncoro pada tahap pembobotan

\begin{tabular}{|l|c|r|c|}
\hline \multicolumn{1}{|c|}{$\begin{array}{c}\text { Jenis } \\
\text { proses }\end{array}$} & $\begin{array}{c}\text { Dampak } \\
\text { terbesar }\end{array}$ & Nilai & Unit \\
\hline $\begin{array}{l}\text { Pemotongan } \\
\text { kain }\end{array}$ & $\begin{array}{c}\text { Climate } \\
\text { change }\end{array}$ & 176.842 & Rupiah \\
\hline Pencucian & $\begin{array}{c}\text { Climate } \\
\text { change }\end{array}$ & 3.084 & Rupiah \\
\hline Penjemuran & - & 0 & Rupiah \\
\hline Nyorek & $\begin{array}{c}\text { Fine } \\
\text { dust }\end{array}$ & 8.155 & Rupiah \\
\hline Nyanting & $\begin{array}{c}\text { Climate } \\
\text { change }\end{array}$ & 27.184 & Rupiah \\
\hline Perendaman & $\begin{array}{c}\text { Climate } \\
\text { change }\end{array}$ & 17.976 & Rupiah \\
\hline $\begin{array}{l}\text { Pewarnaan } \\
\text { pertama }\end{array}$ & Waste & 1.607 .650 & Rupiah \\
\hline
\end{tabular}

Tabel 4.4 Kategori dampak terbesar batik tulis pewarna sintetis Sri Kuncoro pada tahap pembobotan (lanjutan)

\begin{tabular}{|l|c|r|c|}
\hline \multicolumn{1}{|c|}{$\begin{array}{c}\text { Jenis } \\
\text { proses }\end{array}$} & $\begin{array}{c}\text { Dampak } \\
\text { terbesar }\end{array}$ & \multicolumn{1}{c|}{ Nilai } & Unit \\
\hline Pencucian & - & 0 & Rupiah \\
\hline Penjemuran & - & 0 & Rupiah \\
\hline Pengerokan & - & 0 & Rupiah \\
\hline Mbironi & $\begin{array}{l}\text { Climate } \\
\text { change }\end{array}$ & 5.510 & Rupiah \\
\hline Perendaman & $\begin{array}{l}\text { Climate } \\
\text { change }\end{array}$ & 17.976 & Rupiah \\
\hline $\begin{array}{l}\text { Pewarnaan } \\
\text { kedua }\end{array}$ & Waste & 1.607 .650 & Rupiah \\
\hline Pencucian & - & 0 & Rupiah \\
\hline Penjemuran & - & 0 & Rupiah \\
\hline Nglorod & Waste & 1.856 .105 & Rupiah \\
\hline Pencucian & $\begin{array}{l}\text { Climate } \\
\text { change }\end{array}$ & 3.084 & Rupiah \\
\hline $\begin{array}{l}\text { Perendaman } \\
\text { fiksanol }\end{array}$ & Waste & 697.136 & Rupiah \\
\hline Pencucian & $\begin{array}{l}\text { Climate } \\
\text { change }\end{array}$ & 3.084 & Rupiah \\
\hline Pengeringan & - & 0 & Rupiah \\
\hline
\end{tabular}

Tabel 4.5 Kategori dampak terbesar batik tulis pewarna sintetis alternatif pengganti pada tahap pembobotan

\begin{tabular}{|c|c|c|c|}
\hline $\begin{array}{c}\text { Jenis } \\
\text { proses }\end{array}$ & $\begin{array}{c}\text { Dampak } \\
\text { terbesar }\end{array}$ & Nilai & Unit \\
\hline
\end{tabular}




\begin{tabular}{|l|c|r|l|}
\hline $\begin{array}{l}\text { Alternatif } \\
\text { nyanting }\end{array}$ & Fine dust & 19.146 & Rupiah \\
\hline $\begin{array}{l}\text { Alterntaif } \\
\text { mbironi }\end{array}$ & $\begin{array}{l}\text { Climate } \\
\text { change }\end{array}$ & 3.931 & Rupiah \\
\hline $\begin{array}{l}\text { Alternatif } \\
\text { pertama } \\
\text { pewarnaan }\end{array}$ & Waste & 1.622 .265 & Rupiah \\
\hline $\begin{array}{l}\text { Alternatif } \\
\text { kedua } \\
\text { pewarnaan }\end{array}$ & Waste & 1.768 .415 & Rupiah \\
\hline $\begin{array}{l}\text { Alternatif } \\
\text { nglorod }\end{array}$ & Waste & 1.427 .886 & Rupiah \\
\hline
\end{tabular}

Pada Tabel 4.4 dapat diketahui bahwa pada proses pemotongan kain, pencucian, nyanting, perendaman, dan mbironi memilik dampak terbesar pada kategori dampak climate change dengan total dampak Rp 254.739,-. Climate change atau perubahan iklim atau sering dikenal dengan global warming merupakan kondisi dimana suhu bumi semakin meningkat. Beberapa proses di atas tersebut membutuhkan bahan berupa energi listrik dan minyak bumi. Sektor energi listrik merupakan sumber penting gas rumah kaca, khususnya karena energi dihasilkan dari bahan bakar fosil seperti minyak, gas, dan batu bara, dimana batu bara banyak digunakan untuk menghasilkan listrik.

Pada proses pewarnaan pertama, pewarnaan kedua, nglorod dan perendaman fiksanol memilik dampak terbesar pada kategori dampak waste atau limbah dengan total dampak Rp 5.768.541,--. Pada proses tersebut limbah yang dihasilkan adalah limbah cair dan limbah padat. Untuk limbah cair berasal dari penggunaan bahan-bahan kimia pada proses pewarnaan, nglorod, perendaman fiksanol sedangkan limbah padat berasal dari sisa malam yang mencair dan abu kayu bakar pada proses nglorod.

Pada proses nyorek memilik dampak terbesar pada kategori dampak fine dust atau debu sebesar Rp 8.155,-. Pada saat proses tersebut debu yang dihasilkan berasal dari ceceran karbon yang digunakan untuk memola dan asap pembakaran malam pada proses nyanting.

Pada proses yang tidak memiliki kategori dampak dikarenakan pada proses perhitungan di software Simapro tidak memiliki input untuk proses perhitungan.
Sehingga software menerjemahkan bahwa proses tersebut tidak memiliki dampak yang dihasilkan atau dikatakan nol.

Pada Tabel 4.5 dapat diketahui dengan membandingkan dampak penggunaan material/energi di industri batik Sri Kuncoro dengan dampak penggunaan material/energi alternatif pengganti. Dampak yang dihasilkan dari proses nyanting dengan kompor minyak di industri batik Sri Kuncoro terjadi pada kategori dampak climate change sebesar $\mathrm{Rp}$ 27.184,- sedangkan alternatif pengganti dengan kompor listrik terjadi pada kategori dampak fine dust sebesar Rp 19.146,-. Dampak yang dihasilkan dari proses mbironi dengan kompor minyak di industri batik Sri Kuncoro terjadi pada kategori dampak climate change sebesar Rp 5.510,- sedangkan alternatif pengganti dengan kompor listrik terjadi pada kategori dampak climate change sebesar Rp 3.931,-. Dampak yang dihasilkan dari proses pewarnaan dengan pewarna naphtol di industri batik Sri Kuncoro terjadi pada kategori dampak waste sebesar Rp 1.607.650,- sedangkan alternatif pengganti pertama dengan pewarna indigosol terjadi pada kategori dampak waste sebesar $\mathrm{Rp}$ 1.622.265,- dan alternatif pengganti kedua dengan pewarna remazol terjadi pada kategori dampak waste sebesar $\mathrm{Rp}$ 1.768.415,-. Dampak yang dihasilkan dari proses nglorod dengan bahan bakar kayu di industri batik Sri Kuncoro terjadi pada kategori dampak waste sebesar $\mathrm{Rp}$ 1.856.105,- sedangkan alternatif pengganti dengan bahan bakar gas terjadi pada kategori dampak waste sebesar Rp 1.427.886,--

Sehingga dapat disimpulkan bahwa pada proses nyanting dan proses mbironi lebih baik mengggunakan kompor listrik dan pada proses nglorod lebih baik menggunakan bahan bakar gas untuk meminimalisir dampak yang ditimbulkan. Sedangkan pada proses pewarnaan masih tetap sama menggunakan pewarna naphtol yang memiliki dampak paling sedikit dibandingkan penggunaan pewarna yang lainnya.

4.4.2 Analisis hasil Cost Benefit Analysis (CBA)

Biaya bahan untuk pembuatan 12 lembar kain batik tulis pewarna sintetis adalah sebesar Rp 1.923.450,- untuk batik Sri Kuncoro dan sebesar Rp 1.810.400,- untuk 
batik alternatif. Katun primisima yang merupakan bahan utama pembuatan batik yang menyumbang total biaya paling mahal.

Biaya tenaga kerja yang harus dikeluarkan untuk memproduksi 12 lembar kain batik tulis pewarna sintetis adalah sebesar Rp 2.616.000,-. Biaya yang dikeluarkan untuk proses nyanting memiliki nilai paling besar. Biaya tenaga kerja dihitung berdasarkan jumlah berapa lembar batik yang dapat diselesaikan. Proses yang membutuhkan waktu lama yaitu proses nyanting yang membutuhkan kurang lebih 3 hari untuk satu lembar kain batik dengan upah 100.000/lembar kain. Untuk proses pewarnaan tidak masuk dalam perhitungan biaya tenaga kerja karena proses pewarnaan dilakukan langsung oleh pemilik usaha batik.

Baya overhead terdiri dari biaya listrik dan biaya penyusutan alat. Listrik yang digunakan pada industri batik Sri Kuncoro ini memiliki daya sebesar 1300 VA. Kebutuhan yang digunakan selama proses produksi 12 lembar kain batik hanya sebesar 1,44 kwh untuk batik Sri Kuncoro dan sebesar 4,74 untuk batik alternatif. Batik alternatif membutuhkan daya yang lebih besar dibandingkan batik Sri Kuncoro karena penggunaan kompor listrik pada proses nyanting dan proses mbironi. Tarif dasar listrik yang ditetapkan PLN untuk pemakaian daya 1300 VA untuk bulan Mei 2016 sebesar Rp 1.352/kwh. Di dalam perhitungan biaya listrik dikenakan biaya administrasi sebesar Rp 1.600,- dan pajak penerangan jalan sebesar 3\% dari biaya total. Setelah melalui proses perhitungan, biaya listrik yang harus dikeluarkan untuk memproduksi 12 lembar kain batik adalah sebesar Rp 3.657,- untuk batik Sri Kuncoro dan sebesar Rp 8.249,untuk batik alternatif. Di dalam perhitungan biaya penyusutan menggunakan metode straight line (garis lurus). Metode straight line ini mengukur besarnya penyusutan alat yang selalu sama setiap periodenya. Sehingga setelah melakukan perhitungan didapat hasil biaya penyusutan alat pada batik Sri Kuncoro sebesar Rp 138.907,-- dan batik alternatif sebesar Rp 149.827,-. Biaya penyusutan batik alternatif lebih besar dibandingkan batik Sri Kuncoro dikarenakan penggunaan alat kompor gas yang harganya lumayan mahal.

Setelah seluruh biaya dijumlahkan, HPP dari 12 lembar kain batik tulis pewarna sintetis adalah sebesar Rp 4.682.014,- atau Rp 390.168,- per lembar untuk batik Sri Kuncoro dan sebesar Rp 4.584.476,- atau Rp 382.040 ,- per lembar untuk batik alternatif.

Setelah dilakukan perhitungan HPP, kemudian batik tulis pewarna sintetis dihitung net value (keuntungan) dengan cara mengurangkan antara harga jual dengan HPP yang telah dihitung. Harga jual per lembar batik tulis pewarna sintetis adalah $\mathrm{Rp}$ 1.800 .000 ,- sehingga net value batik tulis pewarna sintetis per lembarnya adalah $\mathrm{Rp}$ 1.409.832,- untuk batik Sri Kuncoro dan Rp 1.417.960 untuk batik alternatif. Keuntungan batik alternatif lebih besar dibandingkan batik Sri Kuncoro denagan selisih per lembar sebesar Rp 8.128,-.

4.4.3 Analisis hasil Eco Efficiency Ratio (EER)

Nilai Eco Efficiency Index (EEI) pada proses produksi batik tulis pewarna sintetis Sri Kuncoro sebesar 1,40 dan nilai EEI batik tulis pewarna sintetis alternatif sebesar 1,49, yang berarti batik tulis pewarna sintetis Sri Kuncoro maupun batik tulis pewarna sintetis alternatif bersifat afforable dan sustaiable. Meskipun bersifat sustainable, bukan berarti di dalam proses produksi batik tulis pewarna sintetis tidak memiliki dampak terhadap lingkungan. Batik tulis pewarna sintetis dapat bersifat sustainable karena didukung harga jual yang tinggi dan penggunaan bahan-bahan sintetis yang masih dalam batas normal. Semakin tinggi harga jual suatu produk, maka semakin besar pula nilai EEI. Semakin besar nilai EEI, kemungkinan produk bersifat sustainable akan semakin besar.

Nilai Eco-costs Value Rasio (EVR) pada proses produksi batik tulis pewarna sintetis Sri Kuncoro sebesar 0,44 dan batik tulis pewarna sintetis alternatif sebesar 0,40. Nilai EVR ini diperoleh dengan cara membagi nilai eco-cost dengan net value sebagai nilai ekonomi dari masing-masing produk. Semakin besar net value maka semakin kecil nilai EVR dan semakin kecil EVR yang dihasilkan maka semakin baik dan layak produk tersebut untuk dihasilkan. Hal ini berbanding terbalik dengan nilai EEI yang telah dihitung sebelumnya. Semakin besar nilai EVR maka semakin kecil nilai EEI-nya, begitu juga sebaliknya jika EEI semakin besar maka nilai EVR semakin kecil. 
Nilai Eco Efficiency Ratio (EER) batik tulis pewarna sintetis Sri Kuncoro sebesar $56 \%$ dan batik tulis pewarna sintetis alternatif sebesar 60\%. Semakin tinggi efisiensi dari suatu proses produksi maka akan semakin baik produktivitasnya. Oleh karen itu apabila ingin meningkatkan EER pada suatu produk maka net value dari produk tersebut harus ditingkatkan, dengan kata lain produsen harus menaikkan harga jual suatu produk, sehingga menghasilkan net value yang lebih besar.

\section{KESIMPULAN DAN SARAN \\ 5.1 Kesimpulan}

Dari hasil pengolahan data dan analisis hasil, maka dapat ditarik kesimpulan:

1. Dampak yang dihasilkan dari produksi batik tulis pewarna sintetis Sri Kuncoro sebesar Rp 7.370.353,yang memiliki dampak terbesar pada proses nglorod dengan kategori dampak waste (limbah) sebesar Rp 2.199.426,-. Untuk tingkat efisiensinya cukup tinggi yang bersifat affordable dan sustainable dengan nilai eco efficiency index sebesar 1,40 dan nilai eco efficiency ratio sebesar $56 \%$.

2. Untuk memperbaiki produksi batik tulis pewarna sintetis Sri Kuncoro perlu adanya penggantian material dan energi yang digunakan yaitu pada proses nyanting dan mbironi yang sebelumnya menggunakan kompor berbahan bakar minyak tanah digantikan dengan kompor listrik dengan daya maksimal 200watt dan pada proses nglorod yang sebelumnya menggunakan bahan bakar kayu untuk memanaskan panci penglorodan digantikan dengan bahan bakar gas. Pada proses pewarnaan tetap menggunakan pewarna naphtol karena pewarna tersebut memilik dampak yang paling sedikit dibandingkan menggunakan pewarna indigosol dan remazol.

3. Setelah dilakukan penggantian pada beberapa material dan energi, diperoleh hasil bahwa penggantian tersebut dapat meminimalisir dampak yang dihasilkan dengan dampak sebesar Rp 6.811.058,- dari dampak yang sebelumnya sebesar Rp 7.370.353,--

5.2 Saran

Saran yang diberikan berdasarkan hasil penelitian ini adalah:

1. Diharapkan pada penelitian selanjutnya dapat meneliti alternatifalternatif lain lebih banyak lagi sehingga dapat meminimalisir dampak yang dihasilkan dari produksi batik tulis pewarna sintetis .

2. Untuk industri batik Sri Kuncoro diharapkan mengelola limbah padat maupun limbah cair yang dikeluarkan dalam proses produksi batik lebih baik lagi sehingga limbah yang ada tidak mencemari lingkungan sekitar proses produksi.

\section{DAFTAR PUSTAKA}

Amaya, J., Peggy Zwolinski, and Daniel Brissaud, 2010, Environmental Benets of Parts Remanufacturing: The Truck Injector Case. Jurnal GSCOP Laboratory, https://halsde.archives-ouvertes.fr/hal-

00519559/document, diakses 23 Februari 2016.

Astuti, P., U. Ciptomulyono, dan M. Suef, 2004, Evaluasi Konsep Produk Dengan Pendekatan Green Quality Function Deployment II. Jurnal metode Green Quality Function Deployment (QFD) II, pp 2-3.

Batik Giriloyo, 2015, Giriloyo: Sentra Batik Tulis di Yogyakarta. https://giriloyobatik. wordpress. com, diakses 1 Desember 2015.

Batik Tulis, 2016, Perbedaan Batik Tulis, Batik Cap dan Batik Printing. https://www.

batiktulis.net/posts/40140579326979 1, diakses 15 Mei 2016.

Bayer, Compaq, 2010, Supply Chain Operation Reference (SCOR) Model Version 10.0. Jurnal Supply Chain Council,

http://www.portaldeconhecimentos.o rg.br/index.php/por/content/ download/24758/296095/file/Supply \%20Chain\%20Operations\%20Refere nce\%20(SSCO)\%20model.pdf, 
diakses 23 Februari 2016.

Fiksel, J., 2011, Design for Environment. Amerika Serikat: McGraw-Hill.

Fitinline, 2016, Pewarna Sintetis. https://www.fitinline.com/article/rea d/pewarna-sintetis, diakses 15 Mei 2016.

Hur, Tak, Song-Tack Lim, dan Hye-Jin Lee, 2003. A Study on The Ecoefficiencies for Recycling Methods of Plastics Waste. Jurnal Dept of Material Chemistry \& Enggineering Konkuk University, http://www.lcacenter.org/InLCALCM03/Hur-presentation.pdf, diakses 2 Februari 2016.

Katura, A.R., 2016, Perbedaan antara Batik Tulis, Batik Cap dan Batik Printing. http://sanggar batikkatura. com/category/galeri, diakses $15 \mathrm{Mei}$ 2016.

Nisa, F., A. Tunggul Sutan Haji, Bambang Suharto, dan Sukrisno Widyotomo, 2015, Penentuan Tingkat Ekoefisiensi Proses Produksi Biji Kakao Menggunakan Life Cycle Assessment Pada Unit Produksi di Pusat Penelitian Kopi dan Kakao Indonesia. Jurnal Sumberdaya Alam dan Lingkungan, pp 32-39, Teknik Lingkungan Universitas Brawijaya, Malang.

Agustin, D.P., 2015, 6 Pengertian Pembangunan Berkelanjutan Menurut Para Ahli. Jurnal Universitas Gadjah Mada (UGM), Yogyakarta, http://www.radarplanologi.com/2015 /11/ pengertian-pembangunanberkelanjutan.html, diakses 18 Agustus 2016.

PRe, 2016, SimaPro. https://www.presustainability.com/simapro, PRe Sustainabel, diakses 15 Januari 2016.

Pringgajaya, K. A., dan Udisubakti Ciptomulyono, 2012, Implementasi Life Cycle Assessment (LCA) dan Pendekatan Analytical Network Process (ANP) untuk Pengembangan Produk Hetric Lamp yang Ramah Lingkungan. Jurnal Teknik ITS, No. 1.

Purwanto, 2013, Teknologi Produksi Bersih. Jurnal Badan Penerbit Universitas
Diponegoro, pp 2.

Rousse, Daniel, dan Guillermo Quesada, 2011, Sustainable Buildings: An Ever Evolving Target. Jurnal Sustainabilty, 443-464, www.mdpi.com/2071-1050/3/2/443, diakses 9 Maret 2016.

Sari, Nydhia K., 2013, Pemilihan Material dan Proses Pada Produk Container Plastik Menggunakan Pendekatan Life Cycle Assessment (LCA). Tugas Akhir Teknik Industri UNS, Surakarta.

TU Delft, 2015, The Model of the Eco-costs / Value Ratio (EVR). Delft University, http://www.eco costsvalue.com/, Diakses 20 Desember 2015.

Voglander, Joost G., Charles Hendriks, dan Han Brezet, 2010, LCA-based Assessment of Sustainability: The Eco-Costs/Value Ratio EVR. Jurnal Delf University of Technology, http://www.vanstockum.nl/document / 14463852.pdf, diakses 23 Februari 2016.

Verfaillie, Hendrik A., dan Robin Bidwell, 2000, Measuring Eco-efficiency A Guide to Reporting Company Performance. WBCSD (World Business Council for Sustainable Development), http://www.wbcsd.org/web/publicati ons/measuring_eco_efficiency.pdf, diakses 7 Maret 2016.

Yang, Q. Z, 2007, Life Cycle Assessment in Sustainable Product Design. Jurnal SIMTech Technical Reports, pp 27, https://www.researchgate.net/publica tion/265617116_Life_

cycle_assessment_in_sustainable_pr oduct_design, diakses 8 Maret 2016.

Yulianto, P., 2012, Peningkatan Sustainable dengan Strategi Eko-efisiensi. Tugas Akhir Teknik Industri Universitas Diponegoro, Semarang. 